\author{
Liydmyla Ilich \\ Ph.D. in Economics, Associate Professor, Senior Researcher \\ Department of Social Problems of Labor Market, \\ Ptoukha Institute for Demography and Social Studies of the National Academy of Sciences of Ukraine, Kyiv, \\ Ukraine \\ ilyich1@meta.ua
}

ORCID: 0000-0002-8594-1824

Olena Akilina

Ph.D. in Economics, Associate Professor, Associate Professor of Management Department

Borys Grinchenko Kyiv University, Kyiv, Ukraine

o.akilina@kubg.edu.ua

ORCID: 0000-0001-9968-4921

\title{
IMPACT OF ICT ON LABOR MARKET DEVELOPMENT: MAIN TRENDS AND PROSPECTIVES
}

\begin{abstract}
The level of intellectual activity in developed countries gives evidence concerning innovative economy formation and relevant employment model. The similar trends are being observed in Ukraine. Benefitting from the advantages existing and removal of key curbs regarding ICT introduction are of the actual importance in this country. The active participation of the state in gaining the true balance between technologies development and creation of proper conditions for market gears operation as well as favorable regulatory environment formation will favor ICT development in Ukraine. The specificity of innovative economy and their effect on local labor market and employment are considered in the article. Transformation of labor contents and character, gradual transition from functioning to project activity requires shaping a set of new skills peculiar to labor force as well as universal employee formation who is capable to fulfill both production and organizational duties, be engaged in projects and, correspondingly, who possesses creative abilities and thinking a new way while estimating production processes concerning their interdisciplinary and intercultural links. Based on monitoring examination of labor force skills matching to workplaces requirements the following future skills are shaped: design mindset, systems, project, computational, novel and adaptive thinking, transdisciplinarity, cognitive load management, virtual collaboration, inter-sector communication, project management, programming IT solutions, service orientation, multilingual and multicultural abilities, coordinating with others, artistic skills, ability to work under uncertainty. Prospective future jobs which need above-mentioned skills are analyzed.
\end{abstract}

Keywords: labor market; labor force; occupations; skills; information and communication technologies

Nowadays world community faces the beginning of the $4^{\text {th }}$ industrial revolution. The latest technological changes which took place in the spheres unrelated before such as artificial intelligence, processing power, Big Data, internet of things, mobile internet, cloud technologies, 3D printing ensure the labor production growth, innovative-cost rate intensification and, as a result, lead to improving life quality in the countries focused on informational sector development. Information and communication technologies (ICT) transform the labor market converting labor contents and character, forms of employment, workplaces structure and make new demands for highly skilled labor force training.

Informatization of most public life spheres and activities shows up in new forms of population employment occurrence and growing demand for human resources possessing skills to fulfill information and knowledge-intensive jobs such as management, finances, law, marketing, science and education, mass media, health care, culture etc. Innovative economy requires for personnel handling research, analytical and diagnostic skills which includes information gathering, processing, transfer and storing, as well as communicative skills. The latter means more than simple mastering of speech culture and interpersonal communication, 
it provides for multilingualism, multiculturalism, up-to-date ICT working knowledge and virtual collaboration skills.

The impact of IT on labor market, employment institution and labor process is a subject of research by many foreign and Ukrainian scholars. Among those who contributed most to the issue of employment investigation in information society the following scientists should be mentioned: D. Bell, A. Davies, D. Fidler, M. Gorbis, V. Himpelson, S. Jillette, M. Kastels, A. Kolot, E. Libanova, V. Onikienko, I. Petrova, A. Toffler and others. Large-scale research into this problem was done by World Bank «Connecting to work: how information and communication technologies could help expand employment opportunities» and some investigations are reflected in World Development Report 2016: «Digital Dividends», «Reaping Digital Dividends: Leveraging the Internet for Development in Europe and Central Asia». The yearly monitoring of the ICT development level and its effect on economy and society (Networked Readiness Index, NRI) made by World Economic Forum since 2002 should also be taken into consideration. Alongside, labor market is constantly in progress and permanently changing under the influence of many factors like globalization, ICT advanced growth and ICT penetration in all public spheres, labor market virtualization. All abovementioned stipulates the actual importance of further investigations and identification of contemporary peculiarities of Ukrainian and world labor markets, transformation of labor contents and character in information society. Among Ukrainian and foreign scientists there is no one frame of mind as for objective laws regarding labor market formation and development in information society as well as there is no common opinion on evaluation of innovative economy impact on further labor market advancement. So the research into this range of issues favors scientific searches deepening in this sphere.

The objective of the article is to reveal the specificity of innovative economy and determine the effect of its peculiarities on Ukrainian labor market and employment. To achieve the aim set the following tasks are to be performed: to evaluate the ICT impact on Ukrainian economy, labor contents and character; to explore the labor force skills requirements in ICT and define the future jobs to appear due to such requirements.

Empirical and theoretical methods of economy cognition form the methodological ground for the research. The methods of scientific abstraction, statistical and economic analysis and synthesis, deduction and induction, comparison and bunching, as well as methods of sociological research are applied in the article.

Impact of ICT on Ukrainian economy. The investigation into ICT impact on economy was first revealed at the World Economy Forum in 2001 and depicted in the $1^{\text {st }}$ Global report on Information Technologies. Since that time the level of ICT development and its impact on economy and society has been estimated using NRI, which is made up of four main categories (subindexes), 10 subcategories (pillars) and 53 individual indicators distributed across the different pillars: environment subindex (political and regulatory, business and innovation environment), readiness subindex (infrastructure, affordability, skills), usage subindex (individual, business and government usage), impact subindex (economic and social impacts). The overall NRI score is an average of four subindex scores and equals the range from 1 to 7 .

In 2016 the group of top 10 performers in NRI rating consists of such countries as Singapore and Finland (6.0), Sweden, the USA, Norway, the Netherlands, Switzerland (5.8), the United Kingdom, and Luxembourg (5.7), Japan (5.6) (World Economic Forum, 2012, 2015-2016). As Ukraine ranks $64^{\text {th }}$ place in rating, its position should be compared with CIS countries and Poland. Fig.1 shows Moldova as the bottom ranking state. 


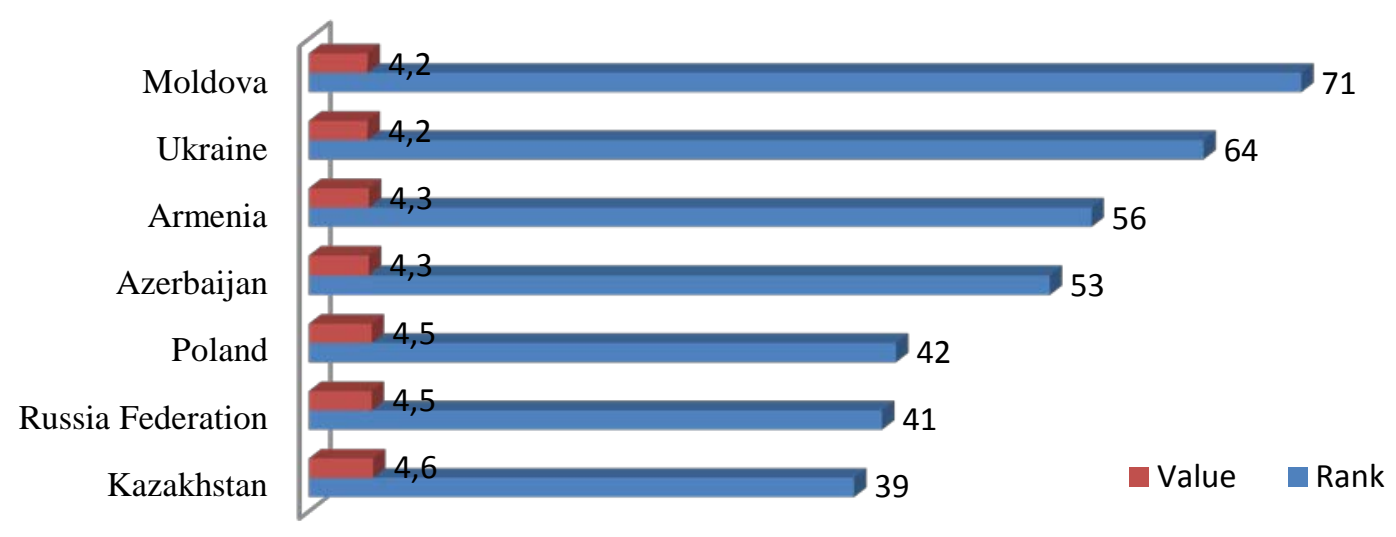

Fig.1 Ukraine and comparing countries in Networked Readiness Index in 2016 Source: World Economic Forum, 2016.

In spite of the fact that for the last four years Ukraine has risen from $75^{\text {th }}$ to $64^{\text {th }}$ place, it couldn't perform substantial positive dynamics of NRI indicators value. Thus, the main task for this country is to benefit from the advantage existing and remove key curbs (see Table 1). The table data indicates that within 2012-2016 among the primary advantages are high level of adult literacy rate (99.8\% in 2016) and high level of tertiary education gross enrollment rate $(82.3 \%$ in 2016). But even improvement of some indicators value does not favor rating ranking rise, which gives evidence that other countries are more active in education and training, particularly quality of math and science education.

The indicator of capacity for innovation has risen to 4.2 for the last four years which enabled Ukraine to climb up 10 places in rating. As for availability of latest technologies Ukraine has a favorable position in the world rating. It is ensured by comparatively low prepaid mobile cellular tariffs and fixed broadband Internet tariffs. Though this advantages may be temporary concerning the situation at telecommunication market.

According to the Economist Intelligence Unit experts' opinion (Information and Analytical Portal HUMANITARIAN TECHNOLOGIES, 2009), the key factors to favor the creation of efficient competitive environment for ICT development are the following: establishing efficient legal regime, open economy based on competitiveness, active participation of the state in gaining the balance between technologies development and maintaining the conditions for market mechanisms operation.

At the same time Ukraine faces the challenge of low efficient national legislative bodies and inefficient legal system of dispute settlement. Despite the power reformation the indicator of judicial independence in 2016 is estimated at 2.3 and the indicator of importance of ICTs to government vision - at 3.1, which have been constant since 2012.

Traditionally Ukraine gets low ranks as for intellectual property protection. Moreover, the indicator of piracy level (the percentage of installed non-licensed software from its overall capacity) reaches $83 \%$. The use of non-licensed software is one of the weighty threats to legal business. Apart from fines, it bears image risks as well as risks of hacking, confidential information leak and contracting viruses. In turn, the use of licensed software is one of the conditions for successful attraction of foreign financial investments, exit to IPO, private placement, bonds floatation etc. 
Table 1

Indicators which favor and restrain the ICT development in Ukraine

\begin{tabular}{|c|c|c|c|c|c|c|c|c|c|}
\hline \multirow{3}{*}{ Indicators } & \multirow{3}{*}{ Contents of indicator } & \multicolumn{6}{|c|}{ Value and rank by years } & \multicolumn{2}{|c|}{ Changes in rank } \\
\hline & & \multicolumn{2}{|c|}{2012} & \multicolumn{2}{|c|}{2015} & \multicolumn{2}{|c|}{2016} & \multirow{2}{*}{$\begin{array}{c}2016 / \\
2012\end{array}$} & \multirow{2}{*}{$\begin{array}{l}2016 \\
2015\end{array}$} \\
\hline & & Value & Rank & Value & Rank & Value & rank & & \\
\hline \multicolumn{10}{|c|}{ Favor the development } \\
\hline Prepaid mobile cellular tariffs & $\begin{array}{c}\text { Average cost of } 1 \mathrm{~min} \text {, } \\
\text { PPP \$/min. }\end{array}$ & 0.07 & 9 & 0.19 & 49 & 0.2 & 48 & $\downarrow 40$ & $\uparrow 1$ \\
\hline Fixed broadband Internet tariffs & $\begin{array}{l}\text { Monthly payment, } \\
\text { PPP \$/min. }\end{array}$ & 16.74 & 9 & 14.10 & 6 & 10.6 & 2 & $\uparrow 3$ & $\uparrow 4$ \\
\hline Mobile network coverage & \% population & 99.9 & 25 & 99.9 & 39 & 99.9 & 37 & $\downarrow 14$ & $\uparrow 2$ \\
\hline Adult literacy rate & $\%$ & 99.7 & 5 & 99.8 & 8 & 99.8 & 9 & $\downarrow 8$ & $\downarrow 1$ \\
\hline Secondary education gross enrollment rate, & $\%$ & 95.6 & 45 & 97.8 & 39 & 99.2 & 51 & $\uparrow 6$ & $\downarrow 12$ \\
\hline Tertiary education gross enrollment rate & $\%$ & 79.5 & 9 & 79.7 & 13 & 82.3 & 11 & $\downarrow 4$ & $\uparrow 2$ \\
\hline Quality of math \& science education & $\begin{array}{l}\text { 1- insufficient; } \\
\text { 7-best }\end{array}$ & 4.6 & 36 & 4.8 & 30 & 4.6 & 38 & $\uparrow 6$ & $\downarrow 8$ \\
\hline Capacity for innovation & $\begin{array}{c}\text { 1- absent; } \\
\text { 7-in its best }\end{array}$ & 3.4 & 42 & 3.6 & 82 & 4.2 & 52 & $\downarrow 40$ & $\uparrow 30$ \\
\hline \multicolumn{10}{|c|}{ Restrain the development } \\
\hline Effectiveness of law-making bodies & $\begin{array}{l}\text { 1- inefficient; } \\
\text { 7-very efficient }\end{array}$ & 2.1 & 137 & 2.5 & 125 & 2.8 & 120 & $\uparrow 12$ & $\uparrow 5$ \\
\hline $\begin{array}{l}\text { Efficiency of legal system in settling } \\
\text { disputes }\end{array}$ & $\begin{array}{c}\text { 1- inefficient; } \\
\text { 7-very efficient }\end{array}$ & 2.3 & 138 & 2.6 & 128 & 2.8 & 121 & $\uparrow 10$ & $\uparrow 7$ \\
\hline Judicial independence & $\begin{array}{l}\text { 1- heavily dependent; } \\
\text { 7- independent }\end{array}$ & 2.0 & 139 & 2.0 & 139 & 2.3 & 131 & unchanged & $\uparrow 8$ \\
\hline Software piracy rate & \% software installed & 84 & 95 & 83 & 91 & 83 & 92 & $\uparrow 3$ & $\downarrow 1$ \\
\hline Venture capital availability & $\begin{array}{c}1 \text { - hard; } \\
7 \text { - simple }\end{array}$ & 2.1 & 114 & 2.3 & 97 & 2.4 & 102 & $\uparrow 17$ & $\downarrow 5$ \\
\hline Total tax rate & $\%$ profits & 57.1 & 118 & 52.9 & 121 & 52.2 & 118 & unchanged & $\uparrow 3$ \\
\hline Intensity of local competition & $\begin{array}{l}1 \text { - non-intensive; } \\
7 \text { - very intensive }\end{array}$ & 4.0 & 120 & 4.7 & 101 & 4.7 & 99 & $\uparrow 19$ & $\uparrow 2$ \\
\hline $\begin{array}{l}\text { Importance of ICTs to government vision } \\
\text { (whether the government has a clear plan on } \\
\text { introduction and use of ICT) }\end{array}$ & $\begin{array}{l}\text { 1- no plan; } \\
\text { 7- has clear plan }\end{array}$ & 3.0 & 122 & 2.7 & 136 & 3.1 & 122 & $\downarrow 14$ & $\uparrow 14$ \\
\hline
\end{tabular}


Practice shows that in countries where the piracy rate is less than $30 \%$ ICT sector of economy produces more than 3,5\% GDP, whereas in the countries with piracy rate more than 85\%, - less than 1,5\% (Official Web Portal Ukraine Parliament, 2012).

According to the research of International Data Corporation (IDC) (Microsoft Ukraine, 2008) each 1 USD spent on purchasing licensed software is worth 1,25 USD spent on associated services including software installment personnel training and technical assistance. Profits from associated services should be directed at new jobs creation for Ukrainian professionals, and corresponding taxes should be transferred to regional and local budgets. Though until now these resources serve shadow economy. According to UDC estimates, reduction of piracy rate in Ukraine by $10 \%$ may lead to positive changes in a range of economic indicators as follows: additional 2600 highly paid jobs will be created for Ukrainian professionals; regional and local budgets will get $69 \mathrm{mln}$. USD from taxation, flow of IT sector will rise in $941 \mathrm{mln}$. USD (Microsoft Ukraine, 2008).

The most favorable situation for creating competitive ICT branch occurs in the countries where venture capital is of integral part in business environment. In Ukraine venture capital availability is limited and charged at 2.4 in 2016 . High tax rate $(52.2 \%$ in 2016) complicated the situation. It is advisable to reveal some statistical data - the share of ICT sector in GDP in the countries-OECD members is nearly $6 \%$ (The World Bank, 2016); in the USA where 8 of 14 greatest companies in the sphere of high technologies are run is $7 \%$, in Ireland this indicator values 12 \% (The World Bank, 2016).

According to the experts' opinion, Ireland is the most attractive state for many foreign companies mainly because of its competitive business environment and beneficial tax rates. These facts should become a positive guideline for Ukraine.

The most favorable situation for creating competitive ICT branch occurs in the countries where venture capital is of integral part in business environment. In Ukraine venture capital availability is limited and charged at 2.4 in 2016. High tax rate (52.2\% in 2016) complicated the situation. It is advisable to reveal some statistical data - the share of ICT sector in GDP in the countries-OECD members is nearly $6 \%$ (The World Bank, 2016); in the USA where 8 of 14 greatest companies in the sphere of high technologies are run is $7 \%$, in Ireland this indicator values 12 \% (The World Bank, 2016). According to the experts' opinion, Ireland is the most attractive state for many foreign companies mainly because of its competitive business environment and beneficial tax rates. These facts should become a positive guideline for Ukraine.

Considering the dynamics of Ukraine's results as for the third subindex 'ICT usage by individuals, businesses, governments' it can be observed some aggravation in values and ranks comparing with 2012 but some improvements while comparing 2015 (see Fig.2).

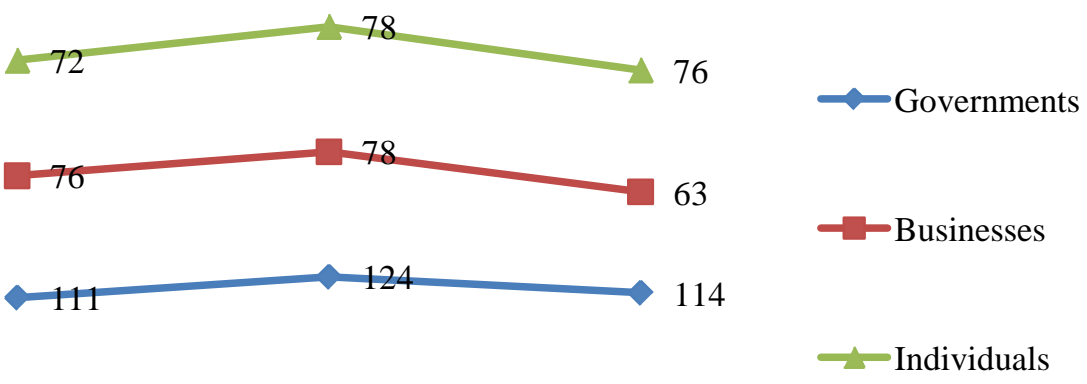

20122015

Fig. 2 Dynamics of Ukraine’s ranks by subindex "ICT usage” Source: World Economic Forum, 2012, 2015-2016. 
As Ukrainian government is estimated as the one which has no clear plan on introduction and use of ICT, low value of ICT in state policy appears as a result, including a low level of ICT priority in government agenda, which leads to worsening of government's ICT use values comparing with 2012.

In 2012-2015 businesses performed negative dynamics in ICT usage which is explained by the fact that low-tech industries requiring little capacity of ICT use were predominated, though positive trends were observed in 2016.

At the same time the dynamics of indicators concerning ICT impact on Ukrainian economy is not positive enough either (see fig.3).

The low level of mastering new technologies is peculiar to Ukraine, so the country ranks 113 by 'Impact of ICTs on business models'. But a significant progress in ICT impact on new organizational models should be noted, in particular, creation of virtual teams, distant work etc. (World Economic Forum, 2012, 2015-2016).

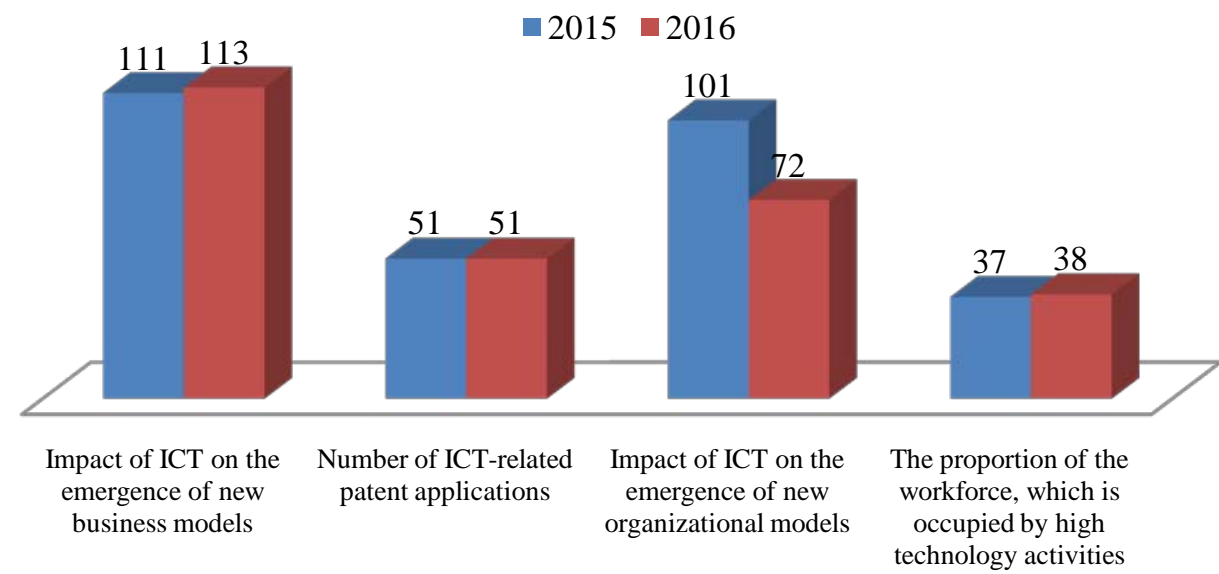

Fig. 3 Dynamics of Ukraine's ranks by subindex “ICT impact” Source: World Economic Forum, 2012, 2015-2016.

Considering ICT impact on economy it makes sense to refer to the World Development Report 'Digital dividends'. The report emphasizes that 'digital dividends' are the spheres in which ICTs produce the broadest development benefits (The World Bank, 2016):

Economic growth. It is estimated that $10 \%$ increase in adaption of broadband internet in export country expands product range in trade turnover between countries by $0.4 \%$. The Internet promotes the opportunity to enter a market quickly. But the most significant contribution of ICT is provided with the cost reduction with simultaneous increase in labor efficiency and productivity in all economy industries;

Job creation. In immediate sphere of digital technologies a few jobs are created, but much more jobs are established in the spheres which are benefitted from ICT introduction. For instance, each job in high-tech industry in the USA creates 4.9 jobs in other economic sectors. Digital economy mainly accounts for expanding the opportunities for entrepreneurship and self-employment;

Services. A vast range of jobs vanished in the economic sectors where the Internet secured the full services automatization and promoted the creation of new digital goods and services. Moreover, the Internet changed substantially the existing services, for instance, taxi service, front office, health care service, education and retailing. Digital technologies allowed granting state services of higher quality and making them more available. 2016):

However, the World Bank emphasizes on the following threats (The World Bank, 
1. $60 \%$ of world population is offline and can't participate in the digital economy in any meaningful way.

2. Venal business interests, the absence of efficient management and a competitive business environment between digital platforms may result in policy capture and greater state control at the market, in such a way favoring natural monopolies, which in future will suppress the working of innovations;

3. Rapid labor automatization even among clerks may result in labor market abandoning. Many advanced economies face increasingly polarized labor markets and rising inequality - in part because technology augments higher skills while replacing routine jobs, forcing many workers to compete for low-paying jobs.

4. The risk occurs that both state and corporations will take advantage of digital technologies to control over the citizens.

In World Bank Group study "Reaping Digital Dividends: Leveraging the Internet for Development in Europe and Central Asia" one more threat is paid much attention to (Kelli, Ljaplina, Tan, \& Uinkler, 2017). In the countries with transition economy such as Ukraine where the Internet is widely spread the substantial care should be taken to measures aimed at labor market regulation. The occurrence of online jobs in shadow economy will result in significant burden reinforcement on state's social security system. Whereas self-employed professionals working on the Internet do not make pension allocations to social funds, the risk is run that they will join the ranks of the poor on reaching the retirement age and be of applicants for public assistance. Estonia is of advisable example to follow as for cooperation between state and online platforms directed at improvement the way of taxation and social payments. But any way innovative forms of employment make the challenge for the social security systems established under terms of traditional forms of employment.

ICT impact on labor contents and character. It should be stated that new technologies introduction in global economic community significantly modifies both world economy structure and labor market. The empowerment of transnational corporations which employ the globalization opportunities is shown up by obtaining competitive advantages from the intensification of production specialization, more intensive labor division and ICTs usage. Scientific and technical progress enabled spatial division of technological process and production diversification considering price factors. Combining the achieved level of interpersonal communication and effect from Internet-focused IAC allowed engaging distant participants specialized in fulfilling regulated functions and operations in labor division.

There is no doubt that scale and pace of distant employment spreading mostly in developed world countries is of great significance and tends to speed up. According to Global Workplace Analytics data, in the USA 50 mln. people (45\% of total workforce) are employed under the terms of occasional distant work, $2.9 \mathrm{mln}$. people work distantly on the permanent base. At the same time an employer saves up to 10000 USD on average per year on each employee if transiting one to distant work. In the UK 62\% of businesses have distant employees, in general, $34 \%$ of employees work outside the office (Global Workplace Analytics, 2016). According to GfK Ukraine forecast, within the nearest two years Ukraine is going to face the rapid increase in distant jobs, whereas the number of enterprises using the distant work format will reach 35\% (Forbes Ukraine, 2016). Such increase is contributed by the businesses which have not employed such format but are eager to do this and by the firms with part-time jobs.

It should also be stated that countries which have a significant share of raw materials export ranks lower in world competitiveness rating than countries with average income level. Economy modernization aimed at transforming resource economic model into innovative knowledge-based model is considered the traditional way-out. It is the main reason why the priority positions will gradually be ranked by high technologies which will be supported with 
wide use of information technologies, computer aids and communication devices, rise in high technological products share in GDP structure connected with production, processing, storing and spreading information and knowledge. In the first place it concerns backing of high technologies development opportunities with wide information technologies introduction. The investigation into countries competitiveness index (by World Economic Forum methodology) reveals that innovative factors linked to business environment growth and innovation spreading are of priority importance as well as fundamental components of competitiveness (institutions, infrastructure, macroeconomic environment, health care and primary education) and efficiency mechanisms (higher education and training, commodity markets development, labor market efficiency, financial markets progress, market scale effect, technological readiness) (World Economic Forum, 2016-2017).

In the world development report "Digital dividends" it is claimed that the share of labor in national income, mainly routine operation labor in many developing countries has significantly been shortened (The World Bank, 2016), with the UK and Ukraine as exceptions. Special skills of some medium-level employees will give them a chance to get more highly paid jobs which make no provisions for routine operations. Technological progress will be of great benefit for such employees. In developing countries people with higher education will take more advantage of education, especially at jobs which require ICT usage. The others will have to search for low-skilled jobs, for instance, in construction maintenance and hotel service. The demand for such services will constantly grow but not sufficiently enough for keeping the previous salary level (The World Bank, 2016).

It should be kept in mind that some jobs vanishing and specific workplaces shortening due to technological progress is essential part of economic growth. It is the productivity growth that provides for economic development and makes human and financial resources available for their use in other branches. It disburdens people to fulfill hard, monotonous and unsafe work. The authors supports the opinion that such trends will be of great benefit for the countries with aging or reducing population as it is observed in Ukraine. It is also of great advantage for the branches which lack skilled workers; this country also experiences the shortage of skilled manual workers.

The requirements for workforce skills in ICTs. Labor intellectualization is closely connected with the increase in significance of mental activity in socially useful work structure. In fact it is stipulated by production mechanization and modernization alongside gradual economic activities and manual jobs displacement. Thus, the process of labor intellectualization is inseparably linked to the processes of human capital intellectual component formation, development and use. In its turn, the potential employee needs to have qualified education and training, be able to support horizontal ties independently, make operative and unusual decisions, possess natural abilities and aptitudes as well as creative thinking and knowledge engaged in intellectual product creation to share with other people.

Labor intellectualization processes lead to active participation of professionals in social production and shaping "knowledge worker" (a wide layer of employees dealing with intellectual labor). That steps up competition at the labor market in the spheres which require the application of mental and creative abilities. Under the conditions when intellectualization process is intensifying employees should focus on constant education and training as well as personal development, be eager to solve a wide range of production tasks requiring nontraditional innovative approaches, searches for nonstandard solutions in various aspects of professional activity. Labor contents and character transformation, gradual transition from functioning to project work force manpower to obtain brand-new set of skills which leads to shaping universal employee capable of fulfilling both production and organization duties, engaged in project work and possessing creative abilities and nonstandard frame of mind while evaluating production processes as for their cross-sectoral and multicultural links. 
Within monitoring research into labor force skills matching to workplaces requirements the survey of employers concerning the skills to be in demand by 2030 was carried out. The results demonstrate that half of them consider as future skills the following: systems thinking, team-working skills, skills of dealing with consumers' requests, skills of managing projects and processes, skills of working under pressure, high level of uncertainty and fast changing of tasks, which force the employees to have quick decision-making skills, flexibility of reacting to working conditions changes, resources distributing and time-management skills. Every third of the questioned among the skills of nearest future mentioned cross-sectoral communication skills providing understanding of technology, processes and market situation in different related/unrelated sectors, systematic thinking meaning the ability to determine complicated systems and deal with them. Every fifth employer noted rise in prospective demand for multilingual and multicultural skills which means the knowledge of foreign languages, understanding of national and cultural context of partner countries, as well as programming IT-decisions, managing of complicated automatic complexes, coping with artificial intelligence. Among other skills 26,7\% of questioned employers mentioned the following ones: cross-industry communication skills, programming IT solutions, engagement in work requiring the search for production challenges decisions; ability to work under time pressure and lack of information; mobility in decision-making process in unconventional situations; skills of technological process rationalization; skills of great database technological processing; inclination to resist undefined situations (Ilich, 2016, pp.475-478).

Considering the ICT sphere specific character, this list may be prolonged. Whereas seven basic skills to be of actual importance in the nearest future should be determined (Davies, Fidler, \& Gorbis, 2011, p.19):

1) design mindset - ability to formulate and present working tasks clearly and accessible to everyone engaged in creative activity;

2) novel and adaptive thinking - ability to think in non-traditional way, finding solutions to the problems beyond habitual scopes, and make decisions using own creative potential which allows to figure out non-traditional ways of solutions to usual production matters;

3) computational thinking - ability to process a huge amount of data defining the mainstream. Considering the fact that data capacity are getting bigger rapidly, this skill encourages everyone to shape the skill of fast data processing of any capacity whereas determining error-free and credible information;

4) project thinking - ability to formulate, set and solve the challenges concerning working processes clearly and transparently. Such way of thinking needs interdisciplinary knowledge providing the opportunity to select different methods and ways of achieving the goal set;

5) transdisciplinarity - versatile outlook enabling efficiently to find the solutions to any task. The mastering of knowledge in different spheres of public life secures deep understanding of various subjects concepts. Employees possessing such skill are able to find the ways of solving any goals set as well as interact successfully with professionals from other branches;

6) cognitive load management - ability to organize the tasks according to their priorities, whereas removing any irrelevant information in order to maximize cognitive functions and human's social development;

7) virtual collaboration -ability to interact with virtual team and organize the working process in virtual environment. Such skills enable an employee of future to organize the production process in virtual environment as well as run it efficiently and improve high productivity. 
Apart from basic skills by 2030 IT workers will need cross-sectoral skills which favor them to work under the conditions of high-speed information and communication technologies and secure the ability to transfer from one branch to another while keeping own competitiveness.

The main cross-sectoral skills to promote improvement in workforce mobility within the ICTs are:

1) systems thinking which means the ability to determine complicated systems and handle them, including system engineering. In fact, systemic thinking is based on comprehension of complicated processes, organizations and mechanisms structure. Possessing this skill, employee will be able to get oriented in the challenge quickly and find the rational solution to tackle it, efficiently adapt a new activity and inform people from other branches and sectors of own ideas. Thus, systemic thinking is cross-sectoral skill which in the nearest future will be inherent to all technicians and managers;

2) inter-sector communication means understanding of technologies, processes and market situations in various related and non-related branches;

3) project management means the ability to use knowledge, experience, methods and tools in project implementation regarding all the requirements set and project members expectations;

4) programming IT solutions means the ability to structure information and handle the production challenges occurred basing on the knowledge of program languages and use of artificial intelligence;

5) service orientation means maximum gratification of consumers' wants regarding their individual tastes and economic possibilities;

6) multilingual and multicultural abilities means the ability to work efficiently in crosscultural environment being master of languages as well as peculiarities of national culture, traditions, customs, moral and ethic norms, being aware of the specificity of working in another country. This skill enables interact successfully in any international company. It is of great use for building-up efficient communication both with potential partners and clients;

7) interpersonal skills means ability to work with individuals, groups, staff using the knowledge of psychology, motivate, encourage and lead them to tackle the productions tasks set;

8) artistic skills means ability for art, having advance aesthetic taste and aptitude to transform own creative experience employing own imagination and spatial intelligence;

9) work under pressure, at high level of uncertainty and fast changing of tasks means aptitude for quick decision-making, rapid reacting to any changes of working conditions, resource-management and time-management.

Though it should be noted that most of skills mentioned above are not shaped within traditional educational system and hard to evaluate. Thereby many countries revise their approaches to education. For instance, Singapore introduces the model of 'aptitude development' which assumes the decrease in tests range and increase in project work capacity.

New jobs caused by ICT spreading. Information and communication technologies are progressing rapidly and affect all economic activities. It is explained by the fact that ICTs account for the rise in data volume transmitting through the Internet, cross-cultural communication expansion, increase in distant workplaces, launch of new amenities for people to communicate while producing, educating, 
Table 2

Jobs for IT sphere until 2030

\begin{tabular}{|c|c|c|c|c|c|c|c|c|c|c|c|}
\hline 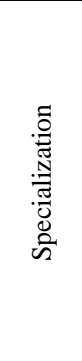 & Job & Job contents & 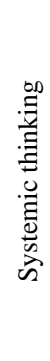 & 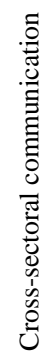 & 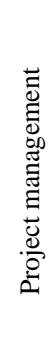 & 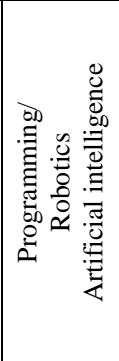 & 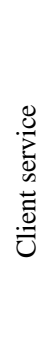 & 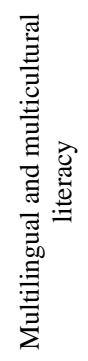 & 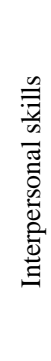 & 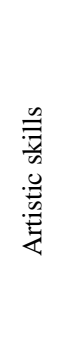 & 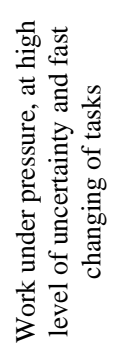 \\
\hline 1 & 2 & 3 & 4 & 5 & 6 & 7 & 8 & 9 & 10 & 11 & 12 \\
\hline \multirow{3}{*}{ 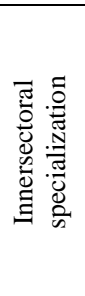 } & Information systems architect & $\begin{array}{l}\text { Skilled worker of wide range of deals with data processing. Database projecting, } \\
\text { procedure algorithmization, deals with customers' handling with database, checks } \\
\text { the data storing, its logics and information removal etc. }\end{array}$ & + & + & + & + & + & & & & + \\
\hline & Neural interface designer & 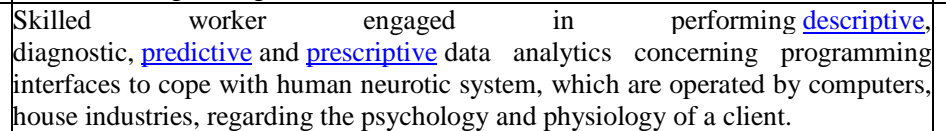 & + & + & + & + & & + & & & + \\
\hline & Big Data model designer & $\begin{array}{l}\text { Skilled worker who programs systems of gathering and processing huge databases } \\
\text { through the Internet, creates interfaces for gathering and analytical models. }\end{array}$ & + & + & + & + & + & & & & + \\
\hline \multirow{2}{*}{ 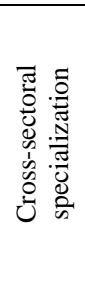 } & Interface designer & $\begin{array}{l}\text { Skilled worker engaged in making simple and friendly, safe and efficient } \\
\text { interfaces for equipment, technical devices, any softs in terms of accomplishing } \\
\text { user goals. }\end{array}$ & + & + & & + & & & + & & + \\
\hline & Virtual architect & $\begin{array}{l}\text { Skilled worker engaged in project making enabling to work, educate and rest in } \\
\text { virtual reality. Makes soft and equipment considering client's bio and psycho } \\
\text { parameters (including individual orders). }\end{array}$ & + & + & + & + & + & & & & + \\
\hline
\end{tabular}


Table 2

\begin{tabular}{|c|c|c|c|c|c|c|c|c|c|c|c|}
\hline 1 & 2 & 3 & 4 & 5 & 6 & 7 & 8 & 9 & 10 & 11 & 12 \\
\hline \multirow{6}{*}{ 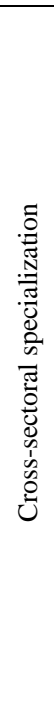 } & $\begin{array}{l}\text { Smart environment cyber } \\
\text { technician }\end{array}$ & $\begin{array}{l}\text { Engaged in conceptual decisions as for virtual worlds: philosophy, natural and } \\
\text { social laws, rules for social interaction and economy, landscapes, architecture, } \\
\text { senses (including smells and tastes), live and natural world }\end{array}$ & + & & & + & + & + & & + & + \\
\hline & Online lawyer & $\begin{array}{l}\text { Skilled worker engaged in shaping legal interaction within the network } \\
\text { (including virtual world), makes the legal regulatory support and intellectual } \\
\text { property protection through the Internet resources }\end{array}$ & + & & & & + & + & & & + \\
\hline & IT communities supervisor & $\begin{array}{l}\text { Skilled worker engaged in organization and modeling of e-forums, gaming and } \\
\text { educational platforms }\end{array}$ & & & + & + & + & + & + & & + \\
\hline & IT preacher & $\begin{array}{l}\text { Skilled worked specialized in communication with final consumers of IT } \\
\text { products, promoting new IT-decisions in groups which are conservative as for } \\
\text { advanced technologies. Trains new program and services and aimed at } \\
\text { shortening the digital gap between humans }\end{array}$ & & & + & + & + & + & + & & + \\
\hline & Digital linguist & $\begin{array}{l}\text { Skilled worker who is engaged in promoting linguistic systems of semantic } \\
\text { translation (concerning the contents and style), text processing (including } \\
\text { semantic search through the Internet) and looking for new interfaces for } \\
\text { communication in natural languages between human and a computer }\end{array}$ & + & + & & + & + & + & & & + \\
\hline & $\begin{array}{l}\text { Information security } \\
\text { supervisor }\end{array}$ & $\begin{array}{l}\text { Skilled worker engaged in information security of Internet users. Compiles the } \\
\text { current information security image of a client based on all of the information, } \\
\text { about them available on the Internet. Audits the client's activities on the Internet } \\
\text { for weak spots, confidentiality and general security. At the client's request, } \\
\text { eliminates weak spots, edits (or deletes) the user's information on the Internet, } \\
\text { and shapes the information image of the clients. }\end{array}$ & + & & & + & + & & + & & + \\
\hline
\end{tabular}

Source: Scolkovo, 2013 
training and entertaining. New jobs of greater demand follow traditional ones concerning scientific and technical progress as well as socio economic development. Table 2 reveals the jobs to be of actual importance in ICT in the nearest 10-13 years (Scolkovo, 2013).

Thus, the results of a survey demonstrate that Ukraine could not perform the positive dynamics as for Networked Readiness Index values. Among the advantages promoting ICTs spreading there are high level of adult literacy rate, high percentage of tertiary education gross enrollment rate, ICT availability. The significant number of curbs on the way of its introduction is being observed: low effectiveness of law-making bodies, inefficiency of legal system in settling disputes, inefficient judicial system, low level of intellectual property rate, high level of privacy rate, problems concerning venture capital availability and high total tax rates. As a consequence, bottom level of ICTs importance to government vision and comparatively low level of their priority in government agenda are observed. Negative dynamics of business ICTs usage is peculiar. Meanwhile we watch substantial progress in ICT impact on new organizational models occurrence.

Anyway, the results of ICT implementation in Ukraine will be of great use concerning the aging population and life expectancy shortening. The industrial branches which lack skilled manual workers will also benefit from that.

Within monitoring survey of labor force skills matching to workplace requirements the authors determined the main skills of future, in particular: design mindset, systems, project, computational, novel and adaptive thinking, transdisciplinarity, cognitive load management, virtual collaboration, inter-sector communication, project management, programming IT solutions, service orientation, multilingual and multicultural abilities, coordinating with others, artistic skills, ability to work under uncertainty.

The list of basic jobs to match the above-mentioned skills in IT sphere by 2030 was made, particularly: information systems architect, neural interface designer, Big Data model designer, interface designer, virtual architect, networking lawyer, IT communities supervisor etc.

Conclusions. ICT development dynamics in this country is closely connected with the government interest in ICT introduction and creation of favorable regulatory environment. Potential benefits from the labor engaging ICT bears specific challenges and risks but positive ICT impact on employment in Ukraine is of evidence if only government and employees are eager to use them.

In the nearest future labor market will experience crucial transformations which were mainly concerning gradual making specific jobs obsolete and establishing new ones which require drastically new approaches to skilled labor force qualifications and training. To be competitive highly skilled worker one needs possessing qualifications as well as professional and cross-sectoral skills which ensure additional advantages and guarantee the chance to adapt rapidly changing market conditions as well as transfer from one economic activity to other.

Thus, the prospective labor market demands in future will be focused on higher level of competitiveness and labor force mobility. This manpower should not only adapt changes but also contribute information and communication technologies into economy as well as efficiently handle projects, staff, organizations and virtual environment. So, contemporary educational establishments should train specialists concentrating on opportunities for professional growth more than on specificity of qualification.

Within the terms of establishing innovative economy in Ukraine the problems of labor market development are of broad arguments and further scientific research. In authors' opinion, new forms of employment, in particular distant employment is of big innovative potential matching the modern world needs and also wants further research. 


\section{REFERENCES} 2011.

Davies, A., Fidler, D., \& Gorbis, M. (2011). Future Work Skills 2020. December 22, http://www.iftf.org/uploads/media/SR1382A_UPRI_future_work_skills_sm.pdfm.

Forbes Ukraine. Observe the distance: a third Ukrainian company employees working remotely. March 1, 2016.

http://forbes.net.ua/ua/business/1411959-dotrimujsya-distanciyi-tretina-pracivnikivukrayinskih-kompanij-pracyue-viddaleno (in Ukrainian).

Global Workplace Analytics. (2016).

http://globalworkplaceanalytics.com/

Ilich, L. (2016). Evaluation of Matching Skills and Jobs. International Relations 2016. Current issues of world economy and politics. Conference proceedings 17th International Scientific Conference Smolenice Castle, 475-481. Bratislava: University of Economics in Bratislava.

Information and Analytical Portal Humanitarian Technologies. (2009). Report of the Economist Intelligence Unit "Stability Among Storms. Comparative analysis of the competitiveness of the IT industry 2009”. September 20, 2009.

http://gtmarket.ru/files/research/Benchmarking-IT-Industry-Competitiveness-2009.pdf (in Russian).

Kelli, T., Ljaplina, A., Tan,S., \& Uinkler, J. (2017). Reaping Digital Dividends: Leveraging the Internet for Development in Europe and Central Asia. March 7, 2017. http://www.worldbank.org/en/region/eca/publication/digital-dividends-in-eca.

Microsoft Ukraine. (2008). Piracy Bulletin 2008.

http://www.google.com.ua/url?sa=t\&rct=j\&q=\&esrc=s\&source=web\&cd=2\&ved=0ahUKEwi 3oaGL1J3UAhVBHCwKHRo2B-kQFggnMAE\&url=http\%3A\%2F\%2Fmsdbdownloads.azurewebsites.net\%2FAntipiracy\%2FPartner_Bulletin_FebruaryMarch_2008.doc\&usg=AFQjCNFCtFgZ-1sQbTbLCrgP29Z4JiUrSg\&sig2=hQZ_18AiIw28_j8PSB5Hw\&cad=rjt. (in Ukrainian).

Official Web Portal Ukraine Parlament. (2012). Recommendations of parliamentary hearings on the topic "Ukraine Create a favorable environment for the development of the software industry”. March 15, 2012.

http://zakon3.rada.gov.ua/laws/show/4538-17 (in Ukrainian).

Scolkovo. (2013). Atlas of emerging jobs. May 14, 2017.

http://atlas100.ru/en.

The World Bank. (2016). World Development Report 2016 “Digital Dividends”. May 17, 2016.

http://documents.worldbank.org/curated/en/

224721467988878739/pdf/102724-WDRWDR2016Overview-RUSSIAN-WebRes-Box-394840B-OUO-9.pdf (in Russian).

World Economic Forum. (2012). The Global Information Technology Report 2012. http://reports.weforum.org/global-information-technology-2012/\#=\&section=chapter-1-1.

World Economic Forum. (2015). The Global Information Technology Report 2015. http://reports.weforum.org/global-information-technology-report-

2015/economies/\#indexId=NRI\&economy=UKR.

World Economic Forum. (2016). The Global Information Technology Report 2016. http://reports.weforum.org/global-information-technology-report-

2016/economies/\#indexId=NRI\&economy=UKR.

World Economic Forum. (2016-2017). The Global Competitiveness Report 2016-2017. http://www.weforum.org. 